\title{
Thyroid Disorders in Patients of Type 2 Diabetes Mellitus
}

\author{
Vibha Uppal · Chittranjan Vij · Gurdeep Kaur Bedi · \\ Anil Vij • Basu Dev Banerjee
}

Received: 30 September 2012/ Accepted: 15 December 2012/Published online: 3 January 2013

(C) Association of Clinical Biochemists of India 2012

\begin{abstract}
The study was planned to assess the prevalence of thyroid disorders in type 2 diabetes in North Indian population and to correlate the serum insulin and glycosylated haemoglobin levels with thyroid hormones. It is a case control study. One hundred and twenty patients of type 2 diabetes were included in the study along with 117 adults of the same age group and normal glucose levels as controls. All blood samples were taken from subjects who fasted for at least $12 \mathrm{~h}$ before the blood collection. Glycosylated hemoglobin was determined by ion exchange chromatography and serum insulin and thyroid hormones were assessed through enzyme linked immunosorbent assay. Fasting blood glucose and glycosylated haemoglobin levels were significantly higher in diabetics showing a poor glucose control. Serum tri-iodothyronine values were significantly lower in diabetics. There was a significant correlation between glycosylated haemoglobin and thyroid hormones. There was no correlation between serum insulin and thyroid hormones.
\end{abstract}

Keywords Glycemic control - Thyroid hormones · Glycosylated haemoglobin · Insulin · Endocrine disorders · Hypothyroidism · Hyperthyroidism

V. Uppal · B. D. Banerjee $(\bowtie)$

Environmental Biochemistry and Molecular Biology Laboratory, Department of Biochemistry, University College of Medical Sciences \& Guru Teg Bhadur Hospital, New Delhi, India e-mail: banerjeebd@hotmail.com

C. Vij · G. K. Bedi

Department of Biochemistry, Government Medical College, Patiala, India

A. Vij

Department of Medicine, Government Medical College, Patiala, India

\section{Introduction}

Thyroid diseases and diabetes mellitus are the two most common endocrine disorders encountered in clinical practice. Diabetes and thyroid disorders have been shown to mutually influence each other and an association between both conditions has been reported in literature [1]. Thyroid disease is a pathological state that can adversely affect glycemic control in diabetics and has the potential to affect the health. Thyroid disease is found commonly in diabetes and is associated with advanced age, particularly in type 2 diabetes and underlying autoimmune disease in type 1 diabetes [2].

Insulin and thyroid hormones are intimately involved in cellular metabolism and thus excess or deficit of either of these hormones result in the functional derangement of the other. The physiological and biochemical interrelationship between insulin and the influence of both insulin and iodothyronines on the metabolism of carbohydrates, proteins and lipids are recorded. Such records indicate that iodothyronines are insulin antagonist with high levels being diabetogenic while absence of the hormone inhibits the development of diabetes [3]. The thyroid hormone replacement is associated with a decrease in glycosylated haemoglobin (HbA1c) level, which is influenced by increased erythropoiesis rather than by changes in glucose level [4].

There is loss of vision in patients of graves disease who have superimposed diabetes and insulin resistance increases the nodularity of thyroid gland. Furthermore, it seems that unidentified thyroid dysfunction could negatively impact diabetes and its complications [1].

Excessive thyroid hormones increase the rate of digestive tract absorption and increase insulin resistance and insulin degradation. In hypothyroidism, liver secretion of 
glycogen decreases, so does degradation, leading to increased levels of glycogen. Absorption of glucose from the gastrointestinal tract is slowed, and glucose utilization is slowed in the peripheral tissues. The availability of gluconeogenic substrate is decreased [2]. Hyperthyroidism impairs glycemic control in diabetic subjects, while hypothyroidism increases susceptibility to hypoglycemia thus complicating diabetes management [1].

There is a continuing interest in the association between thyroid disorders in diabetes mellitus type 2. Furthermore on extensive search of literature we found no major studies have been conducted to compare and correlate serum insulin levels and total tri-iodothyronine (T3), thyroxine (T4), thyroid stimulating hormone (TSH) levels in type 2 diabetes mellitus patients. Data on comparison and correlation of the glycosylated haemoglobin (HbA1c) levels and total T3, T4, TSH levels in type 2 diabetes mellitus patients is also scanty. This study demonstrates the importance of recognition of this mutual relationship between thyroid and insulin hormone which will help guide clinicians on the optimal screening and management of these diseased states.

\section{Methods}

One hundred and twenty patients (in age group of 20-70 years) of type 2 diabetes and 117 adults of the same age group and normal glucose levels who acted as controls were recruited in the study. Approval of the institutional ethics committee was taken. Informed written consent was taken from all subjects. All the diabetic subjects were confirmed diabetics, who previously had fasting plasma glucose levels (FPG) of more than $126 \mathrm{mg} / \mathrm{dL}$ at more than two subsequent occasions and were receiving treatment such as insulin, or oral hypoglycemic agents. In addition, none of the subjects had a history of previous thyroid disease.

Blood specimens from age and sex matched volunteers without history of diabetes mellitus, whose FPG was less than $126 \mathrm{mg} / \mathrm{dL}$ on two different occasions, were the control samples. The study excluded patients with complications of diabetes mellitus and those with known history of thyroid dysfunction (total/subtotal thyroidectomy, patients on ${ }^{131} \mathrm{I}$ treatment, lithium, antithyroid drugs, Graves disease, toxic multinodular goiter, toxic adenoma and carcinoma patients, radiation exposure, gestational hyperthyroidism). Fasting blood samples after $12 \mathrm{~h}$ of fasting were collected.

\section{Specimen Collection}

Five $\mathrm{mL}$ of venous blood was drawn from each subject. It was dispensed into fluoride oxalate bottles for plasma glucose estimation. One EDTA vial containing $0.5 \mathrm{~mL}$ of it was used for estimation of glycosylated haemoglobin and the rest of the blood sample was discharged into a plain sample bottle and allowed to clot. The serum was separated from the red blood cells, divided it into three aliquots and stored them frozen at $-20{ }^{\circ} \mathrm{C}$. Plasma glucose was determined on the same day while all other tests were done within 2 weeks of collection. Fasting plasma glucose estimation was done by the glucose-oxidase peroxidase method, and TSH, T4, T3 and Insulin by enzyme immunoassay (EIA) kit method using commercial kits. We adhered strictly to the manufacturer instructions on the procedures. All sample analysis was done in duplicate and the mean of both the sample analysis used for evaluation.

\section{Investigations}

Glycosylated haemoglobin determined by ion-exchange chromatography as described by Goldstein et al. [5], using ion exchange chromatography kits. ELISA (Diametra kits) were used for serum insulin [6], TSH [7], T3 and T4 estimation [8].

Commercial quality control sera provided with the kits was used to monitor the performance of the procedures. Initially, recovery experiments were performed on each of the parameters TSH, T4, T3 and insulin to assess the accuracy of the methods. Precision was also determined and within and between batches variations was ruled out.

The results of thyroid function were classified on the use of the following as normal reference range:

TSH: $0.39-6.16 \mathrm{mIU} / \mathrm{L}$

T3: $0.49-2.02 \mathrm{ng} / \mathrm{mL}$

T4 (Males): $44-108 \mathrm{nmol} / \mathrm{L}$

T4 (Females): $48-116 \mathrm{nmol} / \mathrm{L}$

Hypothyroidism - when T3, T4 were less and TSH greater than the reference ranges

Hyperthyroidism - when T3, T4 were greater and TSH less than the reference ranges

Subclinical hypothyroidism-when T3, T4 were within normal range and TSH greater than the reference ranges Subclinical hyperthyroidism-when T3, T4 were within normal range and TSH less than the reference ranges

\section{Data Analysis}

Results were analyzed using SPSS ver. 13.00 and Microsoft excel programmes (2007) for $T$ test and correlation coefficient calculations respectively. Minitab 16 statistical analysis software was used for box plot graphing. A comparison of paired data from the two groups of subjects 
was done using $T$ test $(t)$, while a correlation between groups was analyzed using Pearson correlation coefficient $(r)$ formula. $\chi^{2}$ test was used for comparison in two groups for qualitative data. One-way analysis of variance (ANO$\mathrm{VA}=\mathrm{F}$ ) followed by Tukey's test was used to compare grouped data. A two-tailed $p$ value of $<0.05$ were considered indicative of a statistically significance difference.

\section{Results}

Both the diabetic and the control group are age and sex matched. The mean age (in years) of diabetic group is $55.75 \pm 8.45$ and for the control group it is $54.47 \pm 9.24$. The body mass index of diabetic patients $\left(40 \pm 6.1 \mathrm{~kg} / \mathrm{m}^{2}\right)$ was significantly increased compared with that of control subjects $\left(31 \pm 5.9 \mathrm{~kg} / \mathrm{m}^{2}\right)$. Fasting plasma glucose values, glycosylated haemoglobin and serum insulin levels were significantly higher in diabetics as compared to control group (Figs. 1, 2, 3). There was a low serum T3 state in diabetic subjects as compared to the control group. The mean levels of serum T4 and TSH levels were comparable between the two groups. (Table 1) There was a significant negative correlation between glycosylated haemoglobin and serum T3 levels $(r=-0.338, p=0.016)$ and between glycosylated haemoglobin and serum T4 levels $(r=-0.390$, $p=0.005$ ). There was a positive correlation between glycosylated haemoglobin and serum TSH levels as depicted in table $(r=0.424, p=0.002)$. There was no correlation between serum insulin levels $(14.92 \pm 8.42 \mu \mathrm{IU} / \mathrm{mL})$ and thyroid hormone levels (T3, T4, and TSH) (Table 2).

$51.6 \%$ of subjects with normal thyroid profile in the study group had glycosylated haemoglobin of less than $7 \%$. This is in contrast to the fact that $75.8 \%$ subjects diagnosed with abnormal thyroid profile had glycosylated haemoglobin of more than or equal to $8 \%$. (Table 3 ). The mean duration of disease (DM) was $5.98 \pm 4.23$ years in patients with normal thyroid profile in the diabetic group. The mean duration of disease was $12.92 \pm 5.48$ years in patients with abnormal thyroid profile (hypothyroidism or hyperthyroidism). The mean duration of disease was highly significant when both the patient subgroups in the diabetic group were compared (Table 4).

\section{Discussion}

There is a complex interaction between thyroid disorders and diabetes mellitus. In the present study among the 120 diabetic subjects, investigated $17 \%$ i.e. 20 had hypothyroidism and $7.5 \%$ i.e. 9 had hyperthyroidism. Thus a total of $24.5 \%$ patients showed thyroid disorder. Also $5 \%$ i.e. 6 of the control subjects had abnormal thyroid status
Boxplot of Fasting plasma glucose(FPG) $\mathrm{mg} \%$ in Diabetic(D) and Control (C) Group

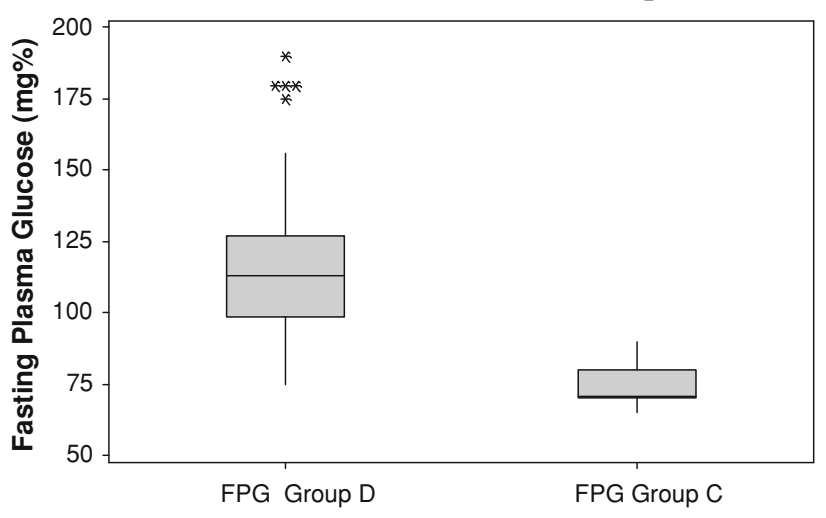

Fig. 1 Fasting plasma glucose in diabetic and control groups

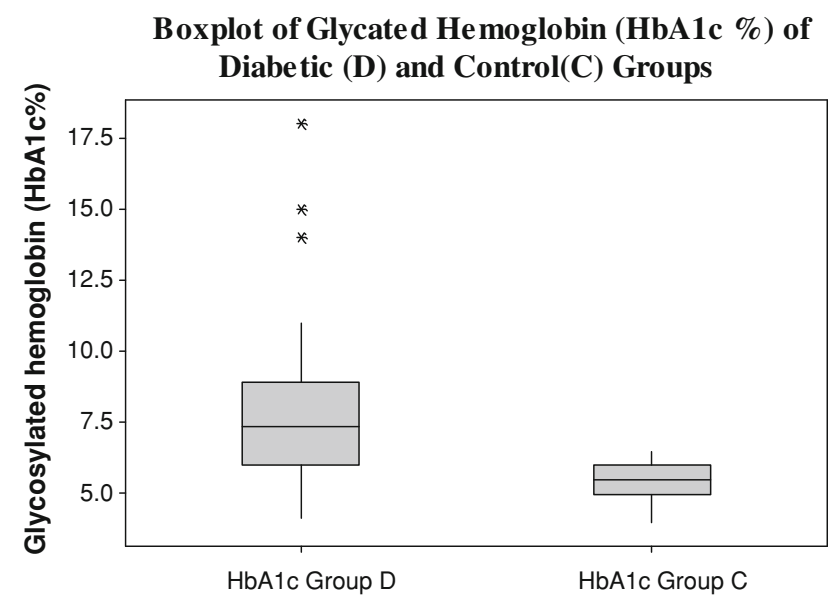

Fig. 2 Glycosylated hemoglobin levels in diabetic and control groups

Boxplot of Serum Insulin in Diabetic(D) and Control(C) group

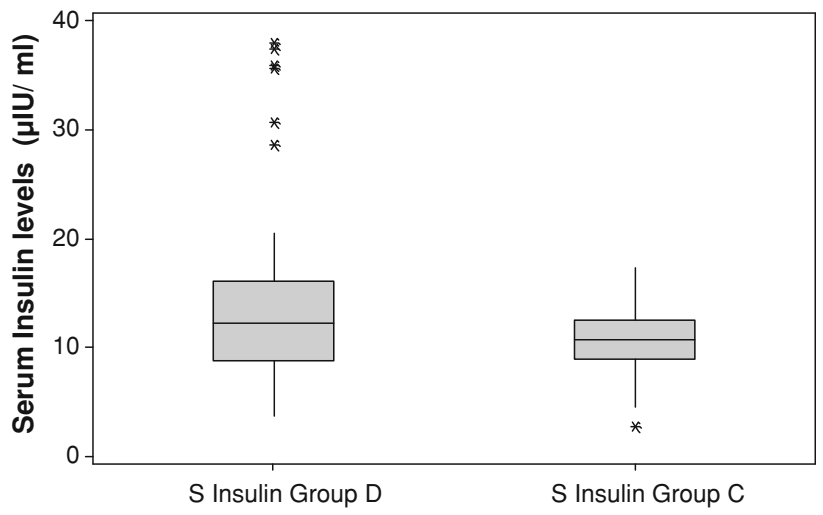

Fig. 3 Serum insulin levels in diabetic and control subjects

(Table 5). These findings show a high incidence of abnormal thyroid hormone levels in diabetic population which is supported by the various studies (Table 6) [9-13]. 
Table 1 Hormone levels in patients of diabetic and control group

\begin{tabular}{llll}
\hline Parameter & $\begin{array}{l}\text { Diabetic group } \\
(n=120)\end{array}$ & $\begin{array}{l}\text { Control group } \\
(n=117)\end{array}$ & $p$ value \\
\hline $\begin{array}{c}\text { Serum insulin } \\
(\mu \mathrm{IU} / \mathrm{mL})\end{array}$ & $14.92 \pm 8.42$ & $10.51 \pm 3.25$ & 0.006 \\
$\begin{array}{c}\text { Serum T3 } \\
(\mathrm{ng} / \mathrm{mL})\end{array}$ & $0.88 \pm 0.35$ & $1.20 \pm 0.46$ & 0.001 \\
$\begin{array}{c}\text { Serum T4 } \\
(\mathrm{nmol} / \mathrm{L})\end{array}$ & $7.22 \pm 2.76$ & $8.11 \pm 3.20$ & 0.104 \\
$\begin{array}{c}\text { Serum TSH } \\
(\mathrm{mIU} / \mathrm{L})\end{array}$ & $4.06 \pm 5.85$ & $2.85 \pm 2.49$ & 0.181 \\
\hline
\end{tabular}

Values are given as mean $\pm \mathrm{SD}$

Table 2 Correlation of serum insulin and HbA1c levels with thyroid hormone levels in diabetic group

\begin{tabular}{|c|c|c|c|c|c|c|}
\hline & \multicolumn{2}{|c|}{ Serum T3 } & \multicolumn{2}{|c|}{ Serum T4 } & \multicolumn{2}{|c|}{ SerumTSH } \\
\hline & $r$ & $p$ & $r$ & $p$ & $r$ & $p$ \\
\hline $\mathrm{HbA1c}$ & -0.338 & 0.016 & -0.390 & 0.005 & 0.424 & 0.002 \\
\hline$S$ insulin & 0.03 & 0.870 & 0.14 & 0.584 & 0.00 & 0.471 \\
\hline
\end{tabular}

$r$ value correlation value

Table 3 Percentage distribution of subjects in diabetic group on basis of glycosylated haemoglobin

\begin{tabular}{lll}
\hline $\begin{array}{l}\text { HbA1c } \\
(\%)\end{array}$ & $\begin{array}{l}\text { \% of subjects with normal } \\
\text { thyroid profile }\end{array}$ & $\begin{array}{l}\text { \% of subjects with abnormal } \\
\text { thyroid profile }\end{array}$ \\
\hline$\leq 7$ & 51.6 & 7 \\
$7-8$ & 24.2 & 17.2 \\
$\geq 8$ & 24.2 & 75.8 \\
\hline
\end{tabular}

Table 4 Comparison of hormones, plasma glucose, HbA1c levels and duration of disease in subjects in normal and abnormal thyroid profile in diabetic group

\begin{tabular}{|c|c|c|c|}
\hline Analyte & $\begin{array}{l}\text { Subjects with } \\
\text { normal thyroid } \\
\text { profile }(n=91)\end{array}$ & $\begin{array}{l}\text { Subjects with } \\
\text { abnormal thyroid } \\
\text { profile }(n=29)\end{array}$ & $p$ value \\
\hline $\mathrm{T} 3(\mathrm{ng} / \mathrm{mL})$ & $0.95 \pm 0.28$ & $0.72 \pm 0.23$ & 0.04 \\
\hline $\begin{array}{l}\mathrm{T} 4 \\
(\mathrm{nmol} / \mathrm{L})\end{array}$ & $7.35 \pm 0.28$ & $6.84 \pm 3.16$ & 0.68 \\
\hline $\begin{array}{l}\mathrm{TSH} \\
(\mathrm{mIU} / \mathrm{L})\end{array}$ & $2.20 \pm 1.62$ & $10.01 \pm 9.66$ & 0.01 \\
\hline $\begin{array}{l}\text { FPG } \\
\qquad(\mathrm{mg} \%)\end{array}$ & $110.40 \pm 24.99$ & $141.5 \pm 29.58$ & 0.001 \\
\hline HbA1c (\%) & $7.30 \pm 2.27$ & $9.65 \pm 2.83$ & 0.001 \\
\hline $\begin{array}{l}\text { Serum } \\
\text { insulin } \\
(\mu \mathrm{IU} / \mathrm{mL})\end{array}$ & $15.33 \pm 9.12$ & $10.81 \pm 6.25$ & 0.110 \\
\hline $\begin{array}{l}\text { Duration of } \\
\text { disease } \\
\text { (years) }\end{array}$ & $5.98 \pm 4.23$ & $12.92 \pm 5.48$ & 0.01 \\
\hline
\end{tabular}

In a study by Moghetti et al. [14], $89 \%$ of patients had hypothyroidism and $11 \%$ had hyperthyroidism. Celani et al. [9] showed maximum prevalence of subclinical hypothyroidism followed by hypothyroidism (23.1\%). Hypothyroidism was shown to be more prevalent thyroid disorder in type 2 diabetics in the studies of Udiong et al. [13]. The presence of both raised and low levels of thyroid hormones levels in diabetics may be due to modified TRH synthesis and release [15].

In our study we found a low T3 state with significantly increased fasting blood glucose, HbA1c and serum insulin in diabetics. The level of TSH was not significantly different in diabetics and non-diabetics. A "Low T3 state" is described as low serum total and free T3 levels but near normal serum T4 and TSH concentrations [16]. Low serum $\mathrm{T} 3$ is due to reduced peripheral conversion of T4 to T3 via $5^{\prime}$ monodeiodination reaction [17]. It is known that insulin, an anabolic hormone enhances the levels of FT4 while it suppresses the levels of T3 by inhibiting hepatic conversion of T4-T3 [13]. TRH synthesis decreases in diabetes mellitus and also there is loss of nocturnal TSH peak which is responsible for the occurrences of low thyroid hormone levels in some diabetics. In euthyroid individuals with diabetes mellitus, the serum T3 levels, basal TSH levels and TSH response to thyrotropin releasing hormone (TRH) all are strongly influenced by the glycemic status [17, 18]. The levels of TSH in our study were not clinically significant in diabetics as compared to non diabetics. This finding is not consistent with the reports of Celani et al., Smithson [9, 10] who recorded varied levels of thyroid hormones in diabetic subjects.

Thyroid stimulating hormone responses and "low T3 state" may normalize with improvement in the glycemic status but even with good diabetes control, the normal nocturnal TSH peak may not be restored in C-peptide negative patients i.e. those with totally absent pancreatic beta cell function [19]. In the present study HbA1c was found to be significantly increased in patients with diabetes, and it was directly proportional to the fasting blood glucose levels. According to Kim et al. [4] hypothyroidism

Table 5 Distribution of diabetic subjects and controls with abnormal thyroid profile

\begin{tabular}{|c|c|c|c|c|}
\hline \multirow[t]{2}{*}{ Thyroid disorders } & \multicolumn{2}{|l|}{ Diabetics } & \multicolumn{2}{|l|}{ Control } \\
\hline & Females & Males & Females & Males \\
\hline Hypothyroid (primary) & 10 & 0 & 4 & 0 \\
\hline Hypothyroid (subclinical) & 8 & 2 & 0 & 0 \\
\hline Hyperthyroid (primary) & 1 & 2 & 2 & 0 \\
\hline Hyperthyroid (subclinical) & 5 & 1 & 0 & 0 \\
\hline \multirow[t]{2}{*}{ Total cases } & 24 & 5 & 6 & 0 \\
\hline & \multicolumn{2}{|l|}{29} & \multicolumn{2}{|l|}{6} \\
\hline
\end{tabular}


Table 6 Studies showing the prevalence of thyroid disorders in type 2 diabetics

\begin{tabular}{ll}
\hline Study & $\begin{array}{l}\text { Prevalence of thyroid } \\
\text { disorders in diabetics (\%) }\end{array}$ \\
\hline Celani et al. [9] & 31.4 \\
Smithson [10] & 10.8 \\
Radaideh et al. [11] & 12.5 \\
Pimenta et al. [12] & 51.6 \\
Udiong et al. [13] & 46.5 \\
Present study & 24.5 \\
\hline
\end{tabular}

falsely raises $\mathrm{HbAlc}$ due to decreased erythropoiesis. Thyroid hormone replacement is associated with a decrease in HbA1c level, which is influenced by increased erythropoiesis rather than by changes in glucose level.

The observation of negative correlation between $\mathrm{T} 3$ and $\mathrm{HbA1c}$ is supported by the views of various authors [17, $20,21]$ who state a derangement of glycemic control in type 2 diabetes which influences the thyroid hormone levels. Furthermore, significant negative correlations were noted between parameters of glycemic control and serum T3 levels respectively. Therefore, the study demonstrated that serum T3 may be a reliable index of glycemic control in diabetes mellitus. It has recently been reported that $\mathrm{T} 3$ has an anti-apoptotic and protective effect on the pancreatic beta cells [20, 21]. T3 activates the PI-3 kinase pathway via thyroid hormone receptor on the beta cell, and stimulates insulin secretion. This may be related to an association between higher FT3 levels, and decreased HbA1c i.e. low total T3 [22, 23].

Our result of a positive correlation between $\mathrm{HbAlc}$ and TSH is consistent with the results by Velija-Asimi et al. [24]. They examined the effects of treatment of subclinical hypothyroidism on metabolic control and hyperinsulinemia and concluded that the correlation between TSH and $\mathrm{HbA1c}$ were positive and significant. Our study showed no correlation between thyroid hormone levels and serum Insulin levels in diabetics. This correlation has never been extensively studied in literature.

\section{Conclusion}

There is higher prevalence of thyroid disorders in type 2 diabetics. This finding is more common in diabetic females. The most common thyroid disorder is hypothyroidism. The association of thyroid disorder with diabetes is more frequent in diabetics who have deranged metabolic control. Thyroid also influences the glycosylated haemoglobin levels. Thus, biochemical screening for thyroid disease is justified in diabetic patients in view of high yield demonstrated in this study and the likelihood of symptoms of thyroid disease being masked by the diabetic state and thyroid aggravating the diabetic picture.

\section{References}

1. Hage M, Zantout MS, Azar ST. Thyroid disorders and diabetes mellitus. J Thyroid Res. 2011;2011:439463.

2. Johnson JL. Diabetes control in thyroid disease. Diabetes Spectr. 2006;19:148-53.

3. Granner DK. Thyroid hormones. In: Murray RK, Granner DK, Mayes PA, Rodwell VW, editors. Harper's Biochemistry. 25th ed. London: Prentice-Hall International Inc.; 2000. p. 533-8.

4. Kim MK, Kwon HS, Baek K, Lee JH, Park WC, Sohn HS, et al. Effects of thyroid hormone on A1C and glycated albumin levels in nondiabetic subjects with overt hypothyroidism. Diabetes Care. 2010;33:2546-8.

5. Goldstein DE, Little RR, Weidmayer HM, England JD, McKenzie EM. Glycated hemoglobin: methodologies \& clinical applications. Clin Chem. 1986;32:B64-70.

6. Frier BM, Ashby JP, Nairn IM, Bairs JD. Plasma insulin, C-peptide and glucagon concentrations in patients with insulinindependent diabetes treated with chlorpropamide. Diabetes Metab. 1981;7:45-9.

7. Spencer CA, Takeuchi M, Kazarosyan M, MacKenzie F, Beckett GJ, Wilkinson E. Interlaboratory/intermethod differences in functional sensitivity of immunometric assays of thyrotropin (TSH) and impact on reliability of measurement of subnormal concentrations of TSH. Clin Chem. 1995;41:367-74.

8. Chopra IJ, Solomon DH, Ho RS. A radioimmunoassay of thyroxine and triiodothyronine. J Clin Endocrinol Metab. 1971;33: $865-8$.

9. Celani MF, Bonati ME, Stucci N. Prevalence of abnormal thyrotropin concentrations measured by a sensitive assay in patients with type 2 diabetes mellitus. Diabetes Res. 1994;27:15-25.

10. Smithson MJ. Screening for thyroid dysfunction in a community population of diabetic patients. Diabet Med. 1998;15:148-50.

11. Radaideh AR, Nusier MK, Amari FL, Bateiha AE, EL-Khateeb MS, Naser AS, et al. Thyroid dysfunction in patients with type 2 diabetes mellitus in Jordan. Saudi Med J. 2004;25:1046-50.

12. Pimenta WP, Mazeto GM, Callegaro CF, Shibata SA, Marins LV, Yamashita $\mathrm{S}$, et al. Thyroid disorders in diabetic patients. Arq Bras Endocrinol Metabol. 2005;49:234-40.

13. Udiong CEJ, Udoh AE, Etukudoh ME. Evaluation of thyroid function in diabetes mellitus in Calabar, Nigeria. Indian J Clin Biochem. 2007;22:74-8.

14. Moghetti P, Castello R, Tosi F, Zenti MG, Magnani C, Bolner A, et al. Glucose counter regulatory response to acute hypoglycemia in hyperthyroid human subjects. J Clin Endocrinol Metab. 1994;78:169-73.

15. de-Greef WJ, Rondeel JM, Van-Haasteren GA, Klootwij KW, Visser TJ. Regulation of TRH production and release in rats. Acta Med Austriaca. 1992;19:77-9.

16. Donckier JE. Endocrine diseases and diabetes. In: Pickup JC, Williams G, editors. Text book of diabetes mellitus. Chichester: Blackwell; 2003. p. 271-2725.

17. Schlienger JL, Anceau A, Chabrier G, North ML, Stephan F. Effect of diabetic control on the level of circulating thyroid hormones. Diabetologia. 1982;22:486-8.

18. Bartalena L, Cossu E, Grasso L, Velluzzi F, Loviselli A, Cirillo R, et al. Relationship between nocturnal serum thyrotropin peak and metabolic control in diabetic patients. J Clin Endocrinol Metab. 1993;76(4):983-7. 
19. Coiro V, Volpi R, Marchesi C, Capretti L, Speroni G, Caffarri G, et al. Influence of residual C-peptide secretion on nocturnal serum TSH peak in well-controlled diabetic patients. Clin Endocrinol (Oxf). 1997;47:305-10.

20. Bagchi N, Brown TR, Parish RF. Thyroid dysfunction in adults over age 55 years. A study in an urban US community. Arch Intern Med. 1990;150:785-7.

21. Verga Falzacappa C, Panacchia L, Bucci B, Stigliano A, Cavallo MG, Bunetti E, et al. 3,5,3'-Triiodothyronine is a survival factor for pancreatic beta cells undergoing apoptosis. J Cell Physiol. 2006;206:309-21.

22. Verga Falzacappa C, Pettruci E, Patriarca V, Michienzi S, Stigliano A, Bunetti E, et al. Thyroid hormone receptor TRbeta1 mediates Akt activation by T3 in pancreatic beta cells. J Mol Endocrinol. 2007;38:221-33.

23. Taneichi $H$, Sasai $T$, Ohara $M$, Honma $H$, Nagasawa $K$, Takahashi $\mathrm{T}$, et al. Higher serum free triiodothyronine levels within the normal range are associated with metabolic syndrome components in type 2 diabetic subjects with euthyroidism. Tohoku J Exp Med. 2011;224:173-8.

24. Velija-Asimi Z, Karamehic J. The effects of treatment of subclinical hypothyroidism on metabolic control and hyperinsulinemia. Med Arh. 2007;61:20-1. 